\begin{tabular}{|l|l|l|l|l|l|}
\hline J. Tek. Ling & Vol. 12 & No. 1 & Hal. 103 - 109 & Jakarta, Januari 2011 & ISSN 1441-318X \\
\hline
\end{tabular}

\title{
PENGARUH EKSPLAN \\ DAN ZPT TERHADAP PERTUMBUHAN NEPENTHES ALBOMARGINATA SECARA IN VITRO
}

\author{
Lazarus Agus Sukamto \\ Peneliti di Pusat Penelitian Biologi Lembaga Ilmu Pengetahuan Indonesia \\ E-mail: lazarus_agus@yahoo.com
}

\begin{abstract}
Nepenthes albomarginata Lobb ex Lindl. is a carnivorous plant, distributes in several regions in Indonesia. The plant population decreases drastically because of over exploitation and ruining nature habitat. Plant propagation by nature and cutting are not enough to rehabilitation its population. In vitro culture of $N$. albomarginata was carried out using plantlets grown from the seeds in vitro. Plantlets were cut to became two part explants, consisted of shoot tip and under-shoot tip cuttings. These cutting explants were grown on Murashige \& Skoog (MS) media with addition of plant growth regulators of 6-benzylaminopurine (BA), combined with or without-naphthalene acetic acid (NAA) or 2,4-dichlorophenoxyacetic acid $(2,4-D)$ at $1 \mathrm{mg} / \mathrm{l}$. Shoot tip cuttings of $\mathrm{N}$. albomarginata formed double multiple shoot $25,00 \%$ on control; formed triple multiple shoots $25,00 \%$ on BA $1 \mathrm{mg} / \mathrm{l}$ treatment; formed callus $37,50 \%$, triple or quartet shoots $25,00 \%$ and rooted plantlets $25,00 \%$ on BA $1 \mathrm{mg} / \mathrm{l}+\mathrm{NAA} 1 \mathrm{mg} / \mathrm{l}$ treatment. The under-shoot tip cuttings of $N$. albomarginata formed double - triple shoots $25,00 \%$ and rooted plantlets $37,50 \%$ on control; formed double - triple shoots $25,00 \%$ and rooted plantlets $12,50 \%$ on BA $1 \mathrm{mg} / \mathrm{l}$ treatment; formed callus $12,50 \%$, double - pentacle shoots $37,50 \%$ and rooted plantlets $25,00 \%$ on $B A 1 \mathrm{mg} / \mathrm{l}+\mathrm{NAA} 1 \mathrm{mg} / \mathrm{l}$ treatment. 2,4-D $1 \mathrm{mg} / \mathrm{l}$ or its combined with $B A 1$ $m g / l$ treatment caused deadly shoot tip or under-shoot tip explants. The combination of BA $1 \mathrm{mg} / \mathrm{l}+\mathrm{NAA} 1 \mathrm{mg} / \mathrm{l}$ was the best treatment for producing callus, multiple shoots and rooted plantlets of $N$. albomarginata.
\end{abstract}

Key words: Nepenthes albomarginata, in vitro, BA, NAA, 2,4-D

\section{PENDAHULUAN}

\subsection{Latar Belakang}

Nepenthes berasal dari kata Yunani yang berarti penghilang rasa sedih yang sangat mendalam, yaitu dengan mencampurnya dengan anggur untuk membuat obat psikotropika yang meningkatkan semangat dan menghasilkan rasa senang. Distribusi Nepenthes terbatas pada daerah tropis Asia, Afrika dan Australia, yaitu dibatasi oleh
Madagaskar, Kepulauan Seychelles, Sri Langka, Australia Utara, termasuk Indonesia dan Malaysia (Pietropaolo and Pietropalo, 1986)1). Genus Nepenthes meliputi 129 species yang merupakan jumlah terbesar dari tanaman pemakan daging (Anonim, 2010) ${ }^{2}$. Habitat tumbuhnya sangat luas, yaitu tebing berkapur yang selalu lembab, ladang pasir yang bermusim basah dan kering, rawa-rawa yang terkadang tergenang 
air, pantai, efipit pada pohon dan menjalar pada permukaan tanah (Pietropaolo and Pietropalo, 1986) ${ }^{11}$.

Nepenthes merupakan tumbuhan menahun herbaceous, berbatang kasar, diameternya dapat mencapai lebih dari $5 \mathrm{~cm}$ dan panjang batangnya dapat mencapai lebih dari $20 \mathrm{~m}$. Batang memanjat, menyerupai semak, pohon atau menjalar di tanah. Batang tumbuhan berbentuk bulat sampai segitiga dengan daun yang panjang menyempit dan ada yang dapat mencapai lebih dari $6 \mathrm{~m}$ panjangnya. Ujung daun umumnya berakhir dengan kantung. Kantung tersebut berisi cairan yang mengandung ensim dan bakteri untuk menangkap dan mencerna mangsanya. Cairan dalam kantung daun yang belum membuka digunakan sebagai obat pencahar, mengobati luka bakar, batuk, radang mata dan berbagai kelainan kulit, sedangkan kantung daun yang sudah membuka digunakan untuk membawa air, wadah memasak makanan. Batangnya digunakan untuk mengurangi demam dan membuat tali. Rebusan akar N. ampullaria digunakan untuk menyembuhkan sakit perut dan desentri di Semenanjung Malaya. Warna kantung daunnya bervariasi, dari hijau muda sampai kuning dengan alur merah dan/ atau ungu. yang tidak beraturan (Perry and Metzger, 19803); Pietropaolo and Pietropalo, 1986) ${ }^{1)}$.

N. albomarginata mempunyai kantung berukuran sampai $15 \mathrm{~cm}$, berwarna merah, ungu atau hitam yang menarik dengan adanya leher kantong berwarna putih (D'Amato, 19984); Anonim, 20102); Merbach and Merbach, 20105)), tergolong tipe yang tumbuh pada dataran rendah, yaitu pada ketinggian di bawah $1000 \mathrm{~m}$ dari permukaan air laut dengan suhu $21^{\circ} \mathrm{C}$ - $29^{\circ} \mathrm{C}$. Daerah penyebarannya meliputi Kalimantan, Sumatera dan Semenanjung Malaya dengan makanan utamanya rayap (Moran et al., 200 ${ }^{16)}$; Merbach and Merbach, $\left.2010^{5}\right)$, berperawakan kecil dan tumbuhnya lambat (Pietropaolo and Pietropalo, 1986)1). Tumbuhan pemakan daging banyak yang mulai langka dan terancam punah di daerah habitatnya karena pengambilan dalam jumlah besar tanpa memperhatikan aspek pelestariannya, penebangan hutan, pengembangan wilayah untuk berbagai macam keperluan, letusan gunung berapi, perubahan iklim dan polusi (Kukulczanka, 19917); D'Amato, 19984); Puspitanyngtyas dan Wawangningrum, 20078)).

Perbanyakan N. albomarginata secara alami melalui biji maupun stek mengalami berbagai hambatan dan memerlukan waktu yang lama. Tumbuhan ini berumah dua, yaitu bunga jantan dan betinanya pada tumbuhan yang berbeda hingga untuk menghasilkan buah dan biji memerlukan penyerbukan silang, sedangkan perbanyakan memalui stek banyak yang tidak berhasil karena kekeringan setelah transport yang jauh dan busuk batang karena jamur atau bakteri di pembibitan. Perbanyakan $\mathrm{N}$. albomarginata secara in vitro dapat menghasilkan tanaman dalam jumlah besar dan waktu yang relatif singkat guna mengurangi tekanan pengambilannya di alam.

Beberapa tumbuhan pemakan daging dan kerabatnya sudah dapat diperbanyak secara in vitro, seperti halnya Urticularia inflexa (Ram et al., 1972)9), Cephalotus follicularis (Adams et al., 1979a) ${ }^{10)}$, Pinguicula moranensis (Adams et al., 1979b)11), P. Iusitanica (Goncaves et al., 2008) ${ }^{12)}$, Drosera intermedia, D. hilaris, $D$. brevifolia, $D$. rotundifolia, $D$. capensis dan D. binata (Kukulczansa, 19917); Anthony, 1992 $\left.{ }^{13)}\right)$, D. omissa (Sukamto, 1999) ${ }^{14)}$, D. peltata (Kim and Jang, 2004) ${ }^{15}$, D. khasiana (Latha and Seeni, 1994) ${ }^{16)}$. Perbanyakan N. albomarginata secara in vitro sangat sedikit dilaporkan. Percobaan dilakukan terhadap tanaman ini yang ditumbuhkan secara in vitro dari biji, planlet yang tumbuh dipotong stek pucuk dan stek bawah pucuknya, yang digunakan sebagai eksplan dan ditanam pada media dasar MS yang berisi berbagai macam ZPT. 


\subsection{Tujuan Penelitian}

Mengetahui stek pucuk atau bawah pucuk yang terbaik untuk dijadikan eksplan dan ZPT yang terbaik untuk perbanyakan tanaman N. albomarginata secara in vitro, serta tujuan konservasinya.

\section{METODOLOGI}

\subsection{Bahan Penelitian}

Material penelitian berupa planlet yang ditumbuhkan dari biji N. albomarginata yang berasal dari Padang, Sumatera Barat, diperbanyak dan dipelihara secara in vitro.

\subsection{Tempat dan Waktu Penelitian}

Percobaan dilakukan di laboratorium Kultur Jaringan, Pusat Penelitian Biologi LIPI, Bogor, dari bulan Februari sampai Juli 2007.

\subsection{Peralatan yang digunakan}

Alat yang digunakan untuk perbanyakan secara kultur jaringan antara lain: laminar air flow cabinet, scalpel, pinset, bunsen, autoklaf, botol kultur, penutup botol.

\subsection{Pembuatan Media Kultur}

Media dasar yang digunakan dalam percobaan ini adalah Murashige and Skoog $(1962)^{17)}$, yang terdiri dari KNO3 1900 $\mathrm{mg} / \mathrm{l}, \mathrm{NH}_{4} \mathrm{NO}_{3} 1650 \mathrm{mg} / \mathrm{l}, \mathrm{CaCl}_{2} .2 \mathrm{H}_{2} \mathrm{O} 440$ $\mathrm{mg} / \mathrm{l}, \mathrm{MgSO}_{4} .7 \mathrm{H}_{2} \mathrm{O} 370 \mathrm{mg} / \mathrm{l}, \mathrm{KH}_{2} \mathrm{PO}_{4} 170$ $\mathrm{mg} / \mathrm{l}$, EDTA $37,3 \mathrm{mg} / \mathrm{l}, \mathrm{FeSO}_{4} \cdot 7 \mathrm{H}_{2} \mathrm{O} 27,8$ $\mathrm{mg} / \mathrm{l}, \mathrm{MnSO}_{4} \cdot 4 \mathrm{H}_{2} \mathrm{O} 22,3 \mathrm{mg} / \mathrm{l}, \mathrm{ZnSO}_{4} \cdot 7 \mathrm{H}_{2} \mathrm{O}$ $8,6 \mathrm{mg} / \mathrm{l}, \mathrm{H}_{3} \mathrm{BO}_{3} 6,2 \mathrm{mg} / \mathrm{l}, \mathrm{KI} 0,83 \mathrm{mg} / \mathrm{l}$, $\mathrm{NaMoO}_{4} \cdot 2 \mathrm{H}_{2} \mathrm{O} 0,25 \mathrm{mg} / \mathrm{l}, \mathrm{CoCl}_{2} \cdot 6 \mathrm{H}_{2} \mathrm{O} 0,025$ $\mathrm{mg} / \mathrm{l}, \mathrm{CuSO}_{4} \cdot 5 \mathrm{H}_{2} \mathrm{O} 0,025 \mathrm{mg} / \mathrm{l}$, myo-inositol $100 \mathrm{mg} / \mathrm{l}$, glycine $3 \mathrm{mg} / \mathrm{l}$, pyridoxine. $\mathrm{HCl}$ 0,5 $\mathrm{mg} / \mathrm{l}$, nicotinic acid $0,5 \mathrm{mg} / \mathrm{l}$, thiamine. $\mathrm{HCl}$ $0,1 \mathrm{mg} / \mathrm{l}$, sukrosa $30 \mathrm{~g} / \mathrm{l}$ dan bahan pemadat phytagel $2 \mathrm{~g} / \mathrm{l}$. Berbagai ZPT ditambahkan sebagai perlakuan, yaitu BA $1 \mathrm{mg} / \mathrm{l}$, BA 1 $\mathrm{mg} / \mathrm{l}+\mathrm{NAA} 1 \mathrm{mg} / \mathrm{l}, 2,4-\mathrm{D} 1 \mathrm{mg} / \mathrm{l}, \mathrm{BA} 1 \mathrm{mg} / \mathrm{l}$ $+2,4-\mathrm{D} 1 \mathrm{mg} / \mathrm{l}$ dan kontrol. Media tersebut diatur $\mathrm{pH}$ nya 5,7 sebelum diautoklaf dan diautoklaf pada suhu $1210 \mathrm{C}$ dan tekanan 1 $\mathrm{kg} / \mathrm{cm} 2$ selama 25 menit.

\subsection{Sampling dan Analisis Sample}

Planlet dipilih yang seragam dan berdaun 10 lembar, dipotong menjadi dua bagian, yaitu stek pucuk dan bawah pucuk yang masing-masing berdaun 5 lembar sebagai eksplan. Tiap eksplan ditanam dalam satu botol kultur yang berisi berbagai media perlakuan. Rancangan percobaan yang digunakan adalah Rancangan Faktorial, yaitu kombinasi antara perlakuan stek pucuk atau bawah pucuk dengan 5 perlakuan ZPT. Tiap perlakuan baik stek pucuk maupun stek bawah pucuk terdiri dari 8 ulangan. Kultur N. albomarginata diinkubasi pada ruang kaca dengan cahaya alami dan suhu diatur sekitar $25^{\circ} \mathrm{C}$. Pengamatan dilakukan setelah 5 bulan tanam, berupa eksplan yang mati, pembentukan kalus, tunas tunggal, tunas ganda dan tunas berakar pada stek pucuk dan bawah pucuk.

\section{HASIL DAN PEMBAHASAN}

\subsection{HASIL}

\subsubsection{Stek pucuk planlet $N$. albomarginata}

Eksplan N. albomarginata mengalami kematian $25,00 \%$, membentuk tunas tunggal $50,00 \%$, tunas ganda 2 sebesar $25,00 \%$, tanpa adanya pembentukan kalus maupun planlet berakar pada kontrol. Eksplan mengalami kematian 50,00\%, membentuk tunas tunggal maupun ganda 3 sebesar $25,00 \%$, tanpa pembentukan kalus maupun planlet berakar pada perlakuan BA $1 \mathrm{mg} / \mathrm{l}$ (Tabel 1).

Eksplan N. albomarginata mengalami kematian $37,50 \%$, membentuk kalus, tunas tunggal maupun ganda 3 - 4 sebesar $37,50 \%$ dan membentuk planlet berakar 
$25,00 \%$ pada perlakuan BA $1 \mathrm{mg} / \mathrm{l}+\mathrm{NAA} 1$ $\mathrm{mg} / \mathrm{l}$. Eksplan tidak respon dan mengalami kematian 100,00\% pada perlakuan 2,4-D 1 $\mathrm{mg} / \mathrm{l}$ maupun kombinasinya dengan BA 1 $\mathrm{mg} / \mathrm{l}$ (Tabel 1).
BA $1 \mathrm{mg} / \mathrm{l}+\mathrm{NAA} 1 \mathrm{mg} / \mathrm{l}$. Eksplan tidak respon dan mengalami kematian $100,00 \%$ pada perlakuan 2,4-D $1 \mathrm{mg} / \mathrm{l}$ maupun kombinasinya dengan BA $1 \mathrm{mg} / \mathrm{l}$ (Tabel 2).

Tabel 1. Prosentase pertumbuhan eksplan stek pucuk N. albomarginata terhadap berbagai perlakuan ZPT

\begin{tabular}{|l|r|r|r|r|r|}
\hline \multicolumn{7}{|c|}{ Perlakuan } \\
\hline Parameter & \multicolumn{1}{|c|}{ Kontrol } & BA1 & BA1+NAA1 & 2,4-D1 & BA1+2,4-D1 \\
\hline Mati & 25,00 & 50,00 & 37,50 & 100,00 & 100,00 \\
\hline Kalus & 0,00 & 0,00 & 37,50 & 0,00 & 0,00 \\
\hline Tunas tunggal & 50,00 & 25,00 & 37,50 & 0,00 & 0,00 \\
\hline Tunas ganda & 25,00 & 25,00 & 25,00 & 0,00 & 0,00 \\
\hline Planlet berakar & 0,00 & 0,00 & 25,00 & 0,00 & 0,00 \\
\hline
\end{tabular}

\subsubsection{Stek bawah pucuk planlet $\mathbf{N}$. albomarginata}

Eksplan N. albomarginata mengalami kematian $12,50 \%$, membentuk tunas tunggal $25,00 \%$, tunas ganda $2-3$ sebesar $25,00 \%$ dan planlet berakar $37,50 \%$, tanpa adanya pembentukan kalus pada kontrol. Eksplan mengalami kematian 37,50\%, membentuk tunas tunggal maupun ganda $2-3$ sebesar $25,00 \%$ dan tunas berakar menurun menjadi $12,50 \%$, tanpa pembentukan kalus pada perlakuan BA $1 \mathrm{mg} / \mathrm{l}$ (Tabel 2).

Eksplan N. albomarginata mengalami kematian $12,50 \%$, membentuk kalus maupun tunas tunggal $12,50 \%$, tunas ganda 2 - 5 sebesar $37,50 \%$ dan membentuk planlet berakar $25,00 \%$ pada perlakuan

\subsubsection{Perbandingan stek pucuk dan bawah pucuk planlet $\mathbf{N}$. albomarginata serta ZPT}

Stek pucuk dan bawah pucuk planlet N. albomarginata berbeda responnya terhadap perlakuan ZPT, yaitu stek bawah pucuk lebih respon dalam membentuk akar dibanding dengan stek pucuk. Tingkat kematian eksplan stek bawah pucuk lebih sedikit dibanding dengan stek pucuk. Eksplan stek pucuk membentuk tunas tunggal yang lebih banyak dibanding dengan eksplan stek bawah pucuk, tetapi hal ini diimbangi dengan pembentukan tunas ganda yang lebih banyak pada stek bawahnya.

ZPT BA $1 \mathrm{mg} / \mathrm{l}$ meningkatkan kematian eksplan dan menurunkan planlet yang

Tabel 2. Prosentase pertumbuhan eksplan stek bawah pucuk N. albomarginata terhadap berbagai perlakuan ZPT

\begin{tabular}{|l|r|r|r|r|r|}
\hline \multicolumn{7}{|c|}{ Perlakuan } \\
\hline Parameter & \multicolumn{1}{|c|}{ Kontrol } & \multicolumn{1}{|c|}{ BA1 } & BA1+NAA1 & 2,4-D1 & BA1+2,4-D1 \\
\hline Mati & 12,50 & 37,50 & 12,50 & 100,00 & 100,00 \\
\hline Kalus & 0,00 & 0,00 & 12,50 & 0,00 & 0,00 \\
\hline Tunas tunggal & 25,00 & 25,00 & 12,50 & 0,00 & 0,00 \\
\hline Tunas ganda & 25,00 & 25,00 & 37,50 & 0,00 & 0,00 \\
\hline Planlet berakar & 37,50 & 12,50 & 25,00 & 0,00 & 0,00 \\
\hline
\end{tabular}


berakar pada eksplan bawah pucuk $\mathrm{N}$. albomarginata. Kombinasi BA $1 \mathrm{mg} / \mathrm{l}+\mathrm{NAA}$ $1 \mathrm{mg} / \mathrm{l}$ menyebabkan pembentukan kalus, planlet berakar pada eksplan pucuk dan meningkatkan tunas ganda pada eksplan bawah pucuk. 2,4-D $1 \mathrm{mg} / \mathrm{l}$ atau kombinasinya dengan BA 1 mg/l menyebabkan eksplan pucuk maupun bawah pucuk menjadi mati.

\subsection{PEMBAHASAN}

\subsubsection{Stek pucuk planlet N. albomarginata}

Eksplan membentuk tunas tunggal $50,00 \%$, tunas ganda 2 sebesar $25,00 \%$, tanpa adanya pembentukan kalus maupun tunas berakar pada kontrol. Diduga eksplan stek pucuk tanaman mengandung cukup zat pengatur tumbuh (ZPT) endogen, terutama jenis sitokinin hingga dapat membentuk tunas ganda, tetapi tidak cukup mengandung ZPT jenis auksin hingga tidak terbentuk kalus maupun tunas berakar.

Eksplan mengalami kematian 50,00\%, membentuk tunas tunggal maupun ganda 3 sebesar $25,00 \%$, tanpa pembentukan kalus dan planlet berakar pada perlakuan BA $1 \mathrm{mg} / \mathrm{l}$. Berarti penambahan BA 1 $\mathrm{mg} / \mathrm{l}$ dari luar meningkatkan konsentrasi BA endogen hingga ke level di atas optimum hingga kematian eksplan menjadi 50,00\%. Pemberian BA 1 mg/l menurunkan pembentukan tunas tunggal menjadi $25,00 \%$ dan terjadi perubahan jumlah tunas ganda 2 menjadi jumlah tunas ganda 3 karena BA merupakan ZPT sitokinin yang mematahkan apikal dominansi dan merangsang pembentukan tunas samping (Bidwell, 1979) ${ }^{18)}$.

Eksplan membentuk kalus dan tunas tunggal sebesar $37,50 \%$, tunas ganda 3 - 4 sebesar $25,00 \%$ dan planlet berakar $25,00 \%$ pada perlakuan BA $1 \mathrm{mg} / \mathrm{l}+\mathrm{NAA}$ $1 \mathrm{mg} / \mathrm{l}$. Nisbah (ratio) ZPT BA dan NAA mempengaruhi morfogenesis eksplan $\mathrm{N}$. albomarginata, yaitu terbentuknya kalus dan akar (Skoog and Miller, 1957)19). Planlet membentuk kalus dan perakaran dikarenakan NAA merupakan ZPT golongan auksin yang merangsang pembentukan kalus dan akar.

Eksplan stek pucuk planlet $\mathrm{N}$. albomarginata mengalami kematian 100,00\% pada perlakuan 2,4-D $1 \mathrm{mg} / \mathrm{l}$ maupun kombinasinya dengan BA $1 \mathrm{mg} / \mathrm{l}$, berarti tanaman ini peka terhadap 2,4-D, yang pada konsentrasi $1 \mathrm{mg} / \mathrm{l}$ sudah mematikan semua eksplan. Kombinasi 2,4-D 1 mg/l dan BA 1 $\mathrm{mg} / \mathrm{l}$ juga tidak memperbaiki respon eksplan N. albomarginata.

\subsubsection{Stek bawah pucuk planlet $\mathbf{N}$. albomarginata}

Eksplan mengalami kematian 12,50\%, membentuk tunas tunggal $25,00 \%$, tunas ganda 2 - 3 sebesar $25,00 \%$ dan planlet berakar $37,50 \%$, tanpa adanya pembentukan kalus pada kontrol. Ini menunjukkan eksplan stek bawah pucuk juga mengandung cukup ZPT endogen sitokinin untuk merangsang terbentuknya tunas ganda, tetapi tidak mengandung cukup auksin endogen hingga tidak terbentuk kalus. Eksplan stek bawah pucuk dapat membentuk tunas berakar. Ini dikarenakan auksin yang diproduksi pucuk tanaman dialirkan ke bawah, makin bawah stek makin besar akumulasi auksin yang berfungsi untuk membentuk akar.

Eksplan mengalami kematian 37,50\% dan planlet berakar menurun menjadi $12,50 \%$, tanpa pembentukan kalus pada perlakuan BA $1 \mathrm{mg} / \mathrm{l}$. Ini menunjukkan penambahan BA sebesar $1 \mathrm{mg} / \mathrm{l}$ menyebabkan peningkatan BA endogen yang meningkatkan kematian eksplan. Penambahan BA menurunkan pembentukan akar disebabkan BA bersifat antagonis terhadap auksin yang berfungsi untuk pembentukan akar maupun kalus.

Eksplan mengalami kematian $12,50 \%$, membentuk kalus maupun tunas tunggal $12,50 \%$, ganda $2-5$ sebesar $37,50 \%$ dan membentuk planlet berakar $25,00 \%$ pada perlakuan BA $1 \mathrm{mg} / \mathrm{l}$ + NAA $1 \mathrm{mg} / \mathrm{l}$. Ini berarti terjadi sinergisme kombinasi antara kedua ZPT tersebut hingga menurunkan 
prosentase kematian eksplan, meningkatkan terbentuknya tunas ganda maupun planlet yang berakar. Jumlah tunas per eksplan juga meningkat, yaitu antara 2 sampai 5 tunas per eksplan dan terbentuk kalus sebesar $12,50 \%$.

Eksplan tidak respon dan mengalami kematian $100,00 \%$ pada perlakuan 2,4-D $1 \mathrm{mg} / \mathrm{l}$ maupun kombinasinya dengan BA $1 \mathrm{mg} / \mathrm{l}$. Ini menunjukkan eksplan tersebut sangat peka terhadap 2,4-D dan konsentrasi $1 \mathrm{mg} / \mathrm{l}$ meracuni dan mematikan semua eksplan. Kombinasinya dengan BA 1 mg/l tidak menunjukkan perbaikan respon eksplan tersebut.

\subsubsection{Perbandingan stek pucuk dan bawah pucuk planlet $\mathrm{N}$. albomarginata serta ZPT}

Stek bawah pucuk lebih respon dalam membentuk akar dibanding dengan stek pucuk karena stek bawah tanaman tempat terbentuknya akar secara alami setelah tanaman tumbuh menjadi besar sampai tingkat tertentu. Kemungkinan stek bawah pucuk telah membentuk primordial akar sebelum dilakukan pemotongan tanaman menjadi dua bagian. Tingkat kematian eksplan stek bawah pucuk lebih sedikit dibanding dengan stek pucuk. Ini dapat dipahami karena diameter stek bawah pucuk lebih besar hingga lebih banyak mengandung cadangan makanan dibanding dengan stek pucuk. Eksplan stek pucuk membentuk tunas tunggal yang lebih banyak dibanding dengan eksplan stek bawah pucuk, tetapi hal ini diimbangi dengan pembentukan tunas ganda yang lebih banyak pada stek bawah pucuk karena hilangnya pengaruh apikal dominansi. Perlakuan BA $1 \mathrm{mg} / \mathrm{l}$ meningkatkan kematian eksplan disebabkan kandungan BA endogen sudah cukup tinggi hingga konsentrasi kumulatif BA melebihi level optimum yang dapat menghambat pertumbuhan. Kombinasi BA $1 \mathrm{mg} / \mathrm{l}+$ NAA $1 \mathrm{mg} / \mathrm{l}$ menginduksi pembentukan kalus dan akar dikarenakan
NAA suatu ZPT auksin yang berperan dalam pembentukan kalus maupun akar dan nisbah BA dan NAA mempengaruhi morfogenesis eksplan (Bidwell, 1979)18). Perlakuan 2,4D $1 \mathrm{mg} / \mathrm{l}$ atau kombinasinya dengan BA 1 $\mathrm{mg} / \mathrm{l}$ menyebabkan semua eksplan mati, dikarenakan $\tan \mathrm{N}$. albomarginata termasuk tanaman yang peka terhadap 2,4-D yang merupakan herbisida kuat pada tanaman berdaun lebar.

\section{KESIMPULAN \& SARAN}

\subsection{KESIMPULAN}

Stek bawah pucuk lebih baik sebagai eksplan dibanding stek pucuk planlet $\mathrm{N}$. Albomarginata karena tingkat kematiannya lebih rendah dan pembentukan akar lebih banyak. Perlakuan ZPT yang terbaik adalah kombinasi BA $1 \mathrm{mg} / \mathrm{l}+\mathrm{NAA} 1 \mathrm{mg} / \mathrm{l}$ karena meningkatkan pembentukan tunas tunggal maupun ganda, dapat membentuk perakaran maupun kalus. Perlakuan ZPT 2,4-D 1 mg/l maupun kombinasinya dengan $B A 1 \mathrm{mg} / \mathrm{lyang}$ terburuk karena menyebabkan kematian eksplan. Tanaman N. albomarginata dapat diperbanyak secara in vitro dalam jumlah yang besar dan waktu yang relatif pendek hingga dapat digunakan untuk meningkatkan populasi dan konservasinya.

\subsection{SARAN}

Perlu penelitian lanjutan untuk mendapatkan planlet $\mathrm{N}$. albomarginata dengan perakaran yang cukup memadai yaitu dengan induksi perakaran dengan menggunakan ZPT golongan auksin sehingga daya hidupnya lebih baik setelah dikeluarkan dari botol kultur.

\section{UCAPAN TERIMA KASIH}

Ucapan terima kasih saya tujukan kepada Dra. Hartutiningsih M. Siregar and Dr. Irawati yang telah memberikan buah $\mathrm{N}$. albomarginata asal dari daerah Padang, 
Sumatera Barat, hingga penelitian ini dapat terwujud.

\section{DAFTAR PUSTAKA}

1. Pietropaolo, J. and P. Pietropaolo, 1986. Carnivorous Plants of the World. Timber Press, Oregon. 206pp.

2. Anonim. 2010. Nepenthes albomarginata. Wikipedia, the Free Encyclopedia. http://en.wikipedia.org/ wiki/Nepenthes_albomarginata. 30 November 2010.

3. Perry, L.M. and J. Metzger, 1980. Medicinal Plants of East and Southeast Asia: Attributed Properties and Uses. The MIT Press, Cambridge, England. 620pp.

4. D'Amato, P. 1998. The Savage Garden, Cultivating Carnivorous Plants. Ten Speed Press. California.

5. Merbach, M. \& D. Merbach. 2010. Nepenthes From Borneo - Nepenthes albomarginata. http://nepenthes. merbach.net/english/_albomarginata. html. 30 November 2010.

6. Moran, J.A., M.A. Merbach, N.J. Livingston, C.M. Clarke and W.E. Booth. 2001. Termite Prey Specialization In The Pitcher Plant Nepenthes albomarginata - Evidence From Stable Isotope Analysis. Ann. Bot. 88:307-311.

7. Kukulczanka, K., 1991. Micropropagation and In Vitro Germplasm Storage of Droseracea.Botanic Gardens Micropropagation News 1(4):37-42.8.

8. Puspitaningtyas, D.M. \& H. Wawangningrum. 2007. Diversitas Nepenthes di Taman Nasional Sulasih Talang - Sumatra Barat. Biodiversitas 8(2):152-156.

9. Ram, M.H.Y., H. Harada and J.P. Nitsch. 1972. Studies on Growth and Flowering in Axenic Cultures of Insectivorous Plants: Effects of Photoperiod, Ethrel, Morphactin and a Few Other Growth
Substances and Metabolic Inhibitors on Urticularia inflexa. Z. Pflanzenphysiol. 68:235-253.

10. Adams, R.M., S.S. Koenigsberg and R.W. Langhans, 1979a. In Vitro Propagation of Cephalotus follicularis (Australian Pitcher Plant). HortScience 144:512-513.

11. Adams, R.M., S.S. Koenigsberg and R.W. Langhans, 1979b. In Vitro Propagation of the Butterwort Pinguicula moranensis H.B.K. HortScience 14(6):701-712.

12. Goncalves, S., A.L. Escapa, Grevenstuk and A. Romano. 2008. An Efficient In Vitro Propagation Protocol for Pinguicula lusitanica, a Rare Insectivorous Plant. Plant Cell Tiss. Organ Cult. 95:239-243.

13. Anthony, J.L.,1992. In Vitro Propagation of Drosera spp. HortScience 27(7):850

14. Sukamto, L.A., 1999. Kultur Daun Drosera omissa Diels Secara In Vitro. Buletin Kebun Raya Indonesia 9(1):1-6.

15. Kim, K.S. \& G.W. Jang. 2004. Micropropagation of Drosera peltata, a Tuberous Sundew, by Shoot Tip Culture. Plant Cell Tiss. Organ Cult. 77:211-214.

16. Latha, P.G. \& S. Seeni. 1994. Multiplication of the Endangered Indian Pitcher Plant (Nepenthes khasiana) Through Enhanced Axillary Branching In Vitro. Plant Cell Tiss. Organ Cult. 38:69-71.

17. Murashige, T. and F. Skoog. 1962. A Revised Medium for Rapid Growth and Bioassays With Tobacco Tissue Cultures. Physiol. Plant. 15:473-497.

18. Bidwell, R.G.S. 1979. Plant Physiology. 2nd edition Macmillan Publishing Co., Inc. New York. 726pp.

19. Skoog, F and C.O. Miller. 1957. Chemical Regulation of Growth and Organ Formation in Plant Tissues Cultured In Vitro. Symp. Soc. Exp. Biol. 11:118-140. 